\title{
THE EFFECT OF SEA CUCUMBER (HOLOTHURIA SCABRA) EXTRACT AS HEPATOPROTECTIVE: HISTOPATHOLOGICAL STUDY
}

\author{
WIDY SUSANTI ABDULKADIR*, ROBERT TUNGADI
}

Department of Pharmacy, Faculty of Sport and Health, State University of Gorontalo, Gorontalo, Indonesia. Email: widisusanti553@yahoo.co.id

Received: 06 June 2018, Revised and Accepted: 03 July 2018

\section{ABSTRACT}

Objective: Sea cucumber Holothuria scabra is one of the marine animals that can be consumed as food and also efficacious as a drug. One of the benefits of sea cucumber has high cell regeneration ability. This study aims to see the profile of hepatoprotective histology of sea cucumber extract on mice that have been given paracetamol toxic dose.

Methods: This experiment was conducted using experimental animal grouped of mice which were divided into six groups: Group I: sea cucumber extract 1\%, Group II: $1000 \mathrm{mg} / \mathrm{kg}$ body weight (BW) or $25 \mathrm{mg} / 25 \mathrm{~g} \mathrm{BW}$, Group III: $750 \mathrm{mg} / \mathrm{kg} \mathrm{BW}$ or $18.75 \mathrm{mg} / 25 \mathrm{~g} \mathrm{BW}$, Group IV: $500 \mathrm{mg} / \mathrm{kg}$ BW or $12.5 \mathrm{mg} / 25 \mathrm{~g}$ BW, Group V: positive control (curcuma tablet $2.5 \mathrm{mg} / 25 \mathrm{~g}$ BW), and Group VI: paracetamol group (62,5 mg/25 g BW). The histopathology test was performed to see the improvement of liver necrosis of mice.

Results: The results of histopathological study showed that all groups of mice livers experienced necrosis (cell damage) and abnormalities. In the group of sea cucumber extract having dose $500 \mathrm{mg} / \mathrm{kg} \mathrm{BW}$, liver cells experienced degeneration of fat and hemorrhage as in the group of curcuma tablet, but in Group VI (paracetamol group), liver of mice experienced apoptosis (cell death). In the histopathology test, results can also be seen that in Group IV at doses of $500 \mathrm{mg} / \mathrm{kg} \mathrm{BW}$, the liver experienced slightly less severity than all other groups.

Conclusion: The sea cucumber at doses of $500 \mathrm{mg} / \mathrm{kg} \mathrm{BW}$ can improve the hepatic damage on mice induced by paracetamol

Keywords: Sea cucumber, Hepatoprotective effect, Histopathology test, Mice, Liver.

(C) 2018 The Authors. Published by Innovare Academic Sciences Pvt Ltd. This is an open access article under the CC BY license (http://creativecommons. org/licenses/by/4. 0/) DOI: http://dx.doi.org/10.22159/ajpcr.2018.v11i9.27747

\section{INTRODUCTION}

Liver is an intermediary organ between the digestive system and blood. One of the important functions of the liver is to protect the body against the occurrence of accumulation of harmful substances such as drugs that inserted into the body from outside. Many of drugs are fat soluble and not easily excreted through urine so that the enzyme system in the liver microsomes will do biotransformation in such way to form a metabolite which is more soluble in water and can be excreted through the urine [1]. Regarding this phenomenon, it is not surprising that the liver has possibilities to be damaged by the drugs. In general, hepatitis due to drugs does not cause permanent damage, but sometimes it can persist and has fatal effect. Hepatotoxic is a chemical causing some toxic effects on liver cells [2]. With the excessive doses (toxic doses) or long-term retreating, this compound can cause an acute or chronic liver damage [3].

The management of liver disease is still a challenge to modern medicine as there is no effective drug available that stimulates liver function, offer protection to the liver from damage or help to regenerate hepatic cells. The only drugs available are corticosteroids and immunosuppressive agents. However, these suffer with several adverse effects. It is, therefore, necessary to search for alternative drugs for the treatment of liver diseases to replace currently used drugs of doubtful efficacy and safety [4]. In the present day scenario, nearly half of the agents used in liver diseases are either natural products or derivatives of natural products due to their ability to act on various biological targets, so there remains a great interest in the search for natural products from plants, terrestrial, and marine animals and microorganisms as potential drug chemical leads for the treatment of a liver disease. Among the wide range of natural sources, herbal and marine source play a key role, where $65 \%$ of patients in US and Europe depend on herbal preparations for the treatment of liver diseases [5].
Utilization of natural materials as a traditional medicine began to be developed, and testing has also been done to obtain more satisfactory results in terms of treatment and the side effects. Sea cucumber Holothuria scabra is marine biota which is widely used as a traditional medicine. Sea cucumber contains antibacterial, antifungal, antitumor, and anticoagulant ingredients. Zancan and Mourao's, 2004, described that in addition to wound healing, sea cucumber extract also contained anticoagulant and antithrombotic compounds [6]. The research that has been done by Abdulkadir, 2010, illustrated that at a concentration of $35 \%$, sea cucumber suspension had hepatoprotective effect and improved liver tissue [7].

Meanwhile, Nurhidayati, 2010, stated that sand cucumber was capable of preventing damage to hepatocytes induced by carbon tetrachloride and the highest protective effect was obtained at a dose of $50 \mathrm{mg} / 200 \mathrm{~g}$ body weight (BW) of the experimental animal. However, there is no real correlation between increasing doses of the sand cucumber with its hepatoprotective effect against carbon tetrachloride. In addition, Novrita and Nurhidayati, 2016, described that $H$. scabra can improve liver fibrosis in mice induced by carbon tetrachloride. Regarding this, Abdulkadir and Tungadi, 2017, found that sea cucumber $H$. scabra extract at a concentration of $1 \%$ can improve the severity level of hepatic damage in mice by reducing the parameter of serum glutamate pyruvic transaminase (SGPT) and serum glutamic oxaloacetic transaminase [8]. Therefore, in this research was continued by describing histopathological study of sea cucumber extract as hepatoprotective effect.

\section{MATERIALS AND METHODS}

Materials

Sea cucumber H. scabra was derived from Wajo village, Tilamuta, Boalemo, Gorontalo, Indonesia. 
Extraction of sea cucumber

The sea cucumber samples were processed by splitting and removing the stomach contents and then washed with clean water until it were clean and free of dirt, then it was cut into small pieces and dried for 2 weeks under the direct sunlight. The dried sample then put into a container of maceration and soaked with methanol until the surface of all sea cucumber was completely immersed. The result then stirred every day 3 times, and the solvent was replaced every 3 days with the same treatment. The extracted solution from the first day to the last day (on the $15^{\text {th }}$ day) was mixed to be evaporated until it produced a viscous sea cucumber extract. The viscous extract was evaporated again at room temperature until dry and then prepared it to the next test.

Preparation of Na-carboxymethyl cellulose (CMC) 1\% suspension The Na-CMC suspension was prepared by dissolving approximately $1.0 \mathrm{~g}$ of $\mathrm{Na}-\mathrm{CMC}$ that had been carefully weighed into $100 \mathrm{ml}$ of distilled water (which had been heated at $70^{\circ} \mathrm{C}$ ) gradually and stirred with an electric stirrer until homogeneous suspension was formed.

Preparation of paracetamol suspension into hepatotoxic dose $250 \mathrm{mg} / \mathrm{kg} \mathrm{BW}$

Paracetamol was suspended into $1 \% \mathrm{Na}-\mathrm{CMC}$ prepared by diluting $625 \mathrm{mg}$ of paracetamol that was carefully measured into $100 \mathrm{~mL}$ of Na-CMC 1\% (hepatotoxic paracetamol $6.25 \mathrm{mg} / 25 \mathrm{~g}$ dose against the mice $\mathrm{BW}$ ).

\section{Preparation of dry extract of sea cucumber into Na-CMC $1 \%$} suspension

The dry extract of sea cucumber was suspended into Na-CMC $1 \%$ suspension made by dissolving the dried extract which had been weighed according to the desired concentration of $1 \% ; 1000 \mathrm{mg} / \mathrm{kg}$ BW, $750 \mathrm{mg} / \mathrm{kg} \mathrm{BW,} 500 \mathrm{mg} / \mathrm{kg} \mathrm{BW}$, curcuma tablet $2.5 \mathrm{mg} / 25 \mathrm{~g} \mathrm{BW}$, and paracetamol group $62.5 \mathrm{mg} / 25 \mathrm{~g} \mathrm{BW}$ of the mice.

\section{Ethical consideration}

Experimental protocols and procedures used in this study were approved by Health Ethics Committee, The Faculty of Medicine, Hasanuddin University, No.325/H4.8.4.5.31/PP36-KOMETIK/2017. All the experimental procedures were carried out in accordance with international guidelines for the care and use of laboratory animals.

Test of dried sea cucumber extract as hepatoprotective effect The treatment group of the dried sea cucumber extract (1\%) was administered orally of $1 \mathrm{ml} / 25 \mathrm{~g}$ BW to the mice, every day for 7 consecutive days, at $30 \mathrm{~min}$ afterward, paracetamol as hepatotoxic dose was administered at a dose of $62.5 \mathrm{mg} / 25 \mathrm{~g} \mathrm{BW}$ mice. On the $8^{\text {th }}$ day, the blood was taken, and the liver surgery was performed (Group I).

This protocol was repeated the same way in the different doses for Group II (1000 mg/kg BW or 25 mg/25 g), Group III (750 mg/kg BW or $18.75 \mathrm{mg} / 25 \mathrm{~g}$ BW), Group IV ( $500 \mathrm{mg} / \mathrm{kg}$ BW or $12.5 \mathrm{mg} / 25 \mathrm{~g} \mathrm{BW}$ ), Group V (2.5 mg/g BW), and Group VI (Na-CMC 1\% solution $1 \mathrm{ml} / 25 \mathrm{~g}$ ).

Histopathological preparation from the mice liver

On the day $9^{\text {th }}$, the liver of the mice was cut with 3-mm microtome then the fixation was conducted. After that, the preparation was inserted successively into $50 \%$ ethanol solution for $30 \mathrm{~min}$, $90 \%$ ethanol for $30 \mathrm{~min}$, and ethanol absolute for $30 \mathrm{~min}$, each having two treatments [9].

The preparation then fed into paraffin-xylol, then sterilized in the oven for $1 \mathrm{~h}$ at $60^{\circ} \mathrm{C}$. The preparation was transferred into the liquid paraffin for $1 \frac{1}{2} \mathrm{~h}$ into the preparatory block. In addition to print, the preparation was cut as thick as 5 microns then attached to a glass object that had been given albumin glycerin and heated at $50^{\circ} \mathrm{C}$ until it was dry. After drying, it was put into pure xylol for 5-10 min. Preparations were taken and fed into ethanol solution $96 \%, 90 \%, 70 \%$, and $50 \%$ for $5-10 \mathrm{~min}$, gradually. The preparation then washed with water then fed into the Ehrlich dye solution for $5 \mathrm{~min}$. The result was washed with clean water then put into ethanol solution gradually of 50\%, 70\%, 90\%, and $96 \%$ and into ethanol absolute. After that, it was inserted into eosin-alcohol for 1-2 min; then, the result was rinsed into water then put into ethanol $50 \%, 70 \%, 90 \%$, and $96 \%$ then into absolute ethanol and xylol. The preparation then dried at room temperature and covered with canned balm and glass objects then observed under a microscope.

\section{RESULTS AND DISCUSSION}

Histological test results can be seen in the Fig. 1 which consisted of six pictures, that is, Group I ( $62.5 \mathrm{mg} / 25 \mathrm{~g} \mathrm{BW}$ of paracetamol dose), Group II (1000 mg/kg BW of sea cucumber extract), Group III (750 mg/kg BB), Group IV (500 mg/kg BW), Group V (curcuma tablet doses of $2.5 \mathrm{mg} / \mathrm{g}$ ), and Group VI (Na-CMC 1\%).

This study used paracetamol induction doses of $62.5 \mathrm{mg} / 25 \mathrm{~g}$ given orally to induce liver cell necrosis and sea cucumber administration performed before paracetamol administration aimed to see the effect of liver protection by sea cucumber extract. Hence, this study focuses on the preventive concept to see the potential of sea cucumber as a hepatoprotective material. The previous study explained that SGPT value on mice which induced paracetamol showed dose $500 \mathrm{mg} / \mathrm{kg}$ of sea cucumber extract had given hepatoprotective effect (SGPT $32 \mathrm{u} / \mathrm{l}$ ) which proven by histological test [8].

From the histological test, this can be seen that all groups of mice liver experience necrosis (cell damage) and abnormalities. In the group of sea cucumber extract on doses $500 \mathrm{mg} / \mathrm{kg} \mathrm{BW}$, liver cells experience degeneration of fat and hemorrhage as in the group of curcuma tablet, but in Group VI (paracetamol group), liver of mice was apoptosis (cell death). In the histopathology test results also seen that in Group IV at
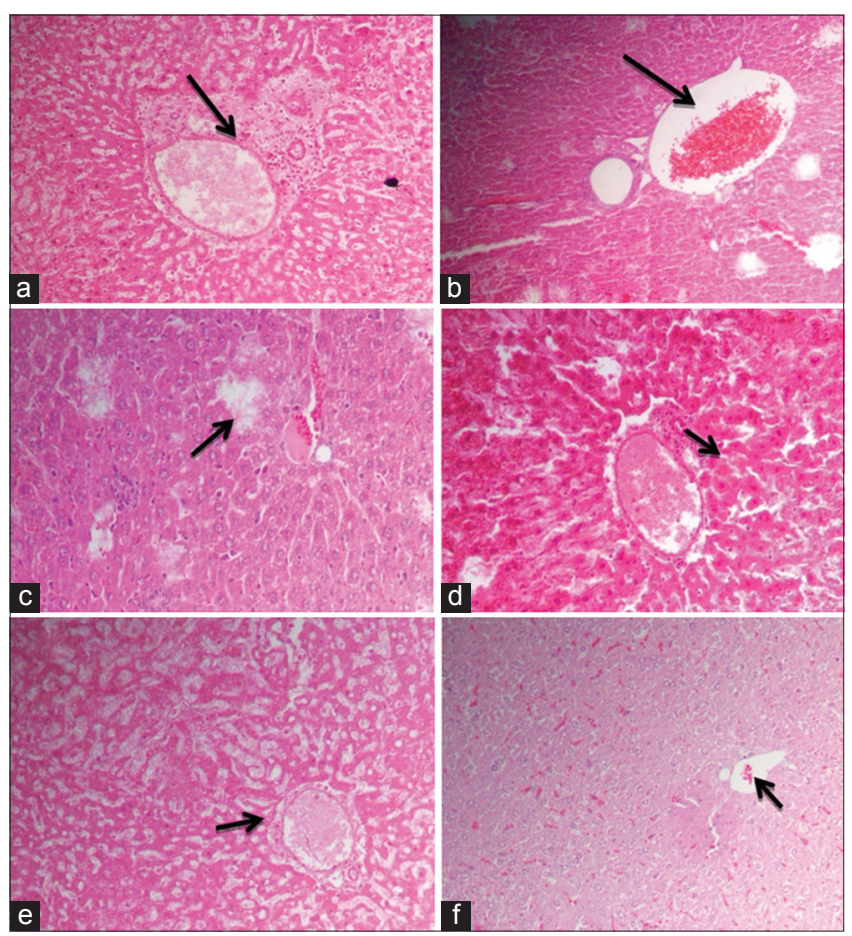

Fig. 1: Photomicrograph of mice livers in the various groups: (a) Group I: Paracetamol doses $(62.5 \mathrm{mg} / 25 \mathrm{~g})$ showing the necrosis histological structure of hepatic lobule; (b) Group II: Sea cucumber extract doses $(1000 \mathrm{mg} / \mathrm{kg} \mathrm{BW})$ showing apparent normal hepatic parenchyma (long narrow); (c) Group III: Sea cucumber extract doses (750 mg/kg BW) showing lipid generation (short narrow); (d) Group IV: Doses of $500 \mathrm{mg} / \mathrm{kg}$ BW showing Küpffer cell activation (short arrow); (e) Group V: Curcuma tablet doses $(2.5 \mathrm{mg} / \mathrm{g})$ showing hepatocyte cell degeneration (short narrow); and (f) Group VI: Na-CMC 1\% showing apparent normal hepatic parenchyma (short narrow) which is similar with Group II 
doses of $500 \mathrm{mg} / \mathrm{kg} \mathrm{BW}$, the liver experience slightly less severity than all other groups.

Histopathologic observations described the effective doses of sea cucumber extract to prevent fatty is at a dose of $500 \mathrm{mg} / \mathrm{kg}$ BW. This is presumably because of the high protein content (86\%) that is easily broken down by the enzyme pepsin, of that amount about $80 \%$ of collagen. Proteins, especially amino acids, glycine, and glutamate, as the main component of glutathione (GSH) are able to reuse by GSH which is exhausted due to the toxicity of paracetamol in cytoplasm and mitochondria. GSH is a robust peroxy-nitrite eliminator and prevents the effective formation of nitro-tyrosine, greatly reduces the necrosis of liver cells due to paracetamol and activates cell regeneration cycles.

This is related to Sharma and Paliwal 2010 research stated that one of the most important antioxidant systems is the GSH redox cycle $[10,11]$. GSH is highly abundant in cytosol, nuclei, and mitochondria and is the major soluble antioxidant in these cell compartments. Reduced GSH, the main component of the endogenous non-protein sulfhydryl pool is known to be a major low-molecular-weight scavenger of free radicals in the cytoplasm [12]. The depletion of GSH promotes the generation of reactive oxygen species and oxidative stress with a cascade of effects, thereby affecting functional as well as the structural integrity of cell and organelle membranes [13]. The elevated level of GSH protects cellular proteins against oxidation through the GSH redox cycle and also directly detoxifies reactive oxygen species and/or neutralizes reactive intermediate species generated from exposure to xenobiotics including chemical carcinogens $[14,15]$.

\section{CONCLUSION}

The extract of sea cucumber at doses of $500 \mathrm{mg} / \mathrm{kg}$ BW can improve the hepatic damage on mice induced by paracetamol.

\section{ACKNOWLEDGMENT}

We would like to thank to the Ministry of Research and Technology of higher education for the support of the funds and the Head of Fisheries Department of Gorontalo Province and also thank you for the Chairman of Commission II of the provincial legislative assembly of Gorontalo for assisting to provide the sample.

\section{AUTHOR'S CONTRIBUTION}

Mrs. Widy S Abdulkadir - Review of literature and data analysis. Mr. Robert - Data collection.

\section{CONFLICTS OF INTEREST}

The authors claim that there are no conflicts of interest.

\section{REFERENCES}

1. Ansari R, Dadbaksh A, Niknahad H, Heidari R, Azarpira N, Hajihashemi F. Hepatoprotective effects of Glycerrhyze aglabra aqueous extract against carbon tetrachloride-induced liver injury in mice. Iran J Pharm Sci 2017;13:146.

2. Nair DG, Weiskirchen R, Al-musharafi SK. The use of marine-derived bioactive compounds as potential hepatoprotective agents. Acta Pharmacol Sin 2015;36:158-70.

3. Syed SH, Namdeo AG. Current status of natural products for the treatment of liver disease - A review. Int J Phytopharm 2014;4:37-43.

4. Adewusi EA, Afolayan AJ. A review of natural products with hepatoprotective activity. J Med Plant Res 2010;4:1318-34.

5. Zhang A, Sun H, Wang X. Recent advances in natural products from plants for treatment of liver diseases. Eur J Med Chem 2013;63:570-7.

6. Zancan P, Mourao PA. Venous and arterial thrombosis in rat models: Dissociation of the antitrombotic effect of glycosaminoglycans. Blood Coagul Fibrinolysis 2004;15:45-54.

7. Abdulkadir WS. The Effect of Sea Cucumber Suspension against Hepatotoxic of Paracetamol on Mice: Histopathological Study. Thesis. Makassar: UNHAS; 2009.

8. Abdulkadir WS, Tungadi R. The hepatoprotective effect of sea cucumber (Holothuria scabra) extract originating from Gorontalo district using SGOT and SGPT parameters on mice induced by hepatotoxic dose of paracetamol. Int J ChemTech Res 2017;10:105-11.

9. Fahmi SR. Anti-fibrotic effect of Holothuria arenicola extractagainst bile duct ligation in rats. BMC Comp Alter Med 2015;15:14.

10. DakroryAI, Harbi MS, MohamedAS. Antioxidant role of Holothuriaatra extract against nephrotoxicity induced by 7, 12-dimethylbenz (a) anthracene in male albino rats. Int J Adv Res 2015;3:275-87.

11. Sharma V, Paliwal R. Chemo protective role of Moringa oleifera and its isolated saponin against DMBA induced tissue damage in male mice: A histopathological analysis'. Int J Drug Dev Res 2012;4:215-28.

12. Toklu ZH, İnac AT, Sehirli OP, Sener G. The protective effect of Nigella sativa oil in the brain of the biliary obstructed rats. Marmara Pharmaceut J 2013;17:46-51.

13. Singh RP, Padmanathi B, Rao AR. Modulatory influence of Adhatoda vesica (Justicia adhatoda) leaf extract on the enzymes of xenobiotic metabolism antioxidant status and lipid peroxidation in mice. Mol Cell Biochem 2000;213:99-109.

14. Kettrer B. Glutathione-S-trensferase and prevention of cellular free radical damage. Free Rad Res 1998;28:647-58.

15. Laksmiani NP, Meiyanto ED, Susanti RA. Cytotoxic activity of Brazilen isolated from secang against MCF7/Dox cells by inhibition of p-glycoprotein. Int J Pharm Pharm Sci 2017;9:124-30. 